\title{
糖尿病の治療戦略と漢方
}

\author{
佐藤 笼造 \\ 愛知学院大学心身科学部健康科学科, 愛知, 干470-0195 日進市岩崎町阿良池 12
}

\section{The Treatment Strategy for Diabetes Mellitus by Kampo Medicine}

\author{
Yuzo SATO
}

Department of Health Science, Faculty of Psychological and Physical Sciences, Aichi Gakuin University 12 Araike, Iwasaki-cho, Nisshin-shi, Aichi 470-0195, Japan

\begin{abstract}
Recently in Japan, the numbers of diabetic patients have been increased to 7.4 million and to 16.2 millions if the subjects of impaired glucose tolerance are added. Most Japanese diabetic patients are type 2 (non-insulin dependent). Decreased secretion of insulin and insulin resistance play important roles on the occurrence and progression of type 2 diabetes.

Long-established systems of traditional medicine have evolved from systematic recordings of human evidence for more than 3 thousands years. In addition the traditional Chinese medicinal philosophy is one of the oldest medical sciences in the world and has a long-standing history in the usage of herbal medicinals. Nowadays the use of complementary/alternative medicine and especially the consumption of botanicals has been increasing rapidly worldwide.
\end{abstract}

\section{Clinical Studies}

The management of diabetic neuropathy is one of the most difficult clinical problems. Among 65 patients with diabetic neuropathy who suffered from numbness of lower extremities $43(66.2 \%)$ experienced some degree of improvement after oral administration of Goshajinkigan (GJG). Following our first report, more than 10 papers were published in Japan and almost same results were obtained. In a well-controlled comparative study, the efficacy of GJG and mecobalamin in diabetic neuropathy was estimated. After oral administration of GJG, the general improvement rate was $80.0 \%$, while it was $48.1 \%$ in mecobalamin. The difference between the two groups was statistically significant $(\mathrm{P}<0.01)$. These results suggested that GJG is a useful medicine for amelioration of numbness due to diabetic neuropathy.

\section{Animal experimental studies}

Regular physical training has been known to be beneficial in the prevention and the treatment of life-style related diseases such as type 2 diabetes. However, it is very difficult for diabetic patients to continue physical exercise training for a long time. Troglitazone has insulin-sensitizing actions but it withdrew because of severe fatal hepato-toxic actions. Therefore development of insulin-sensitizing medicine without significant sideeffects have been expected.

Chinese herbal medicine has less frequent side effects when compared to modern western medicine.

In the present study, the effect of GJG on insulin resistance in streptozotocin (STZ, $50 \mathrm{mg} \mathrm{kg}^{-1} \mathrm{BW}$, ivy.)induced diabetic rats was examined by means of the euglycemic clamp procedure.

The improvement of impaired insulin action in STZ-diabetic rats by single and repeated administration of GJG may be due, at least in part, to enhance insulin signaling, and subsequent ameliorated production of NO.

In conclusion,

(1) Diagnosis and primary treatment to reduce blood glucose including diet, exercise, oral hypoglycemic agents and insulin should be practiced by western style medical sciences. (2) Kampo medication is useful for the prevention and treatment of diabetic complications. (3) Kampo medicine has the possibility of prevention of type 2 diabetes.

Key words : diabetes, diabetic neuropathy, numbness, euglycemic clamp, insulin action

\section{要旨}

糖尿病の漢方治療について 
1 ）糖尿病と合併症，2）糖尿病診療における漢方薬の果たす役割，3）糖尿病神経障害の治療と漢方薬の役割 臨床的研究，4）インスリン抵抗性亡漢方薬：動物実験的研究，5）結語：糖尿病における漢方薬の適応, の項目 で、20年間にわたる私共の臨床的研究成績の一部および最近, 名古屋大学大学院医学系研究科健康・スポーツ医学 分野の大学院生と実施した動物実験成績を紹介した。

1. 臨床的研究

1 ）牛車腎気丸は糖尿病神経障害に由来するしびれを中心とした愁訴の改善に有用である。

2 ）牛車腎気丸の有用性のメカニズムに関して(1)アルドース還元酵素阻害作用，(2皮膚血管拡張に由来する皮膚 温上昇，(3)末梢血管拡張作用にはNO が関与している，等の客観的 evidence が報告されている。

2. 動物実験成績

1 ）覚醒下正常血糖クランプ法を用いた私共の検討成績によれば，牛車腎気丸は単回投与でも，長期間投与（7 日間）によってもストレプトゾトシン（STZ）糖尿病ラットのインスリン抵抗性を改善させる。しかし, NO 合成 阻害薬であるL-NMMA 同時投与により，その効果が消失することから，NOの関与が想定されている。また，イ ンスリンシグナル伝達系の関与も明らかとなっている。

2）桂枝加术附湯についても同様の検討を行ったが, インスリンシグナル伝達経路（牛車腎気丸と一部異なる） を介したインスリン抵抗性改善を認めている。

結語

糖尿病における漢方医学的診療は次のように行うべきと考える。1) 西洋医学的診断・治療を活用する。2 ) 漢方 薬は合併症の早期治療と進展防止に有用である。3 ) 漢方薬は糖尿病（2 型）発症予防に有用である可能性がある。 キーワード : 糖尿病, 糖尿病神経障害, しびれ, 正常血糖クランプ法, インスリン作用

渡辺 教育講演 1 ですが,「糖尿病の治療戦略と 漢方」ということで, 佐藤祐造先生にお話しいただ きます。1998年に「朝日新聞」の第 1 面で日本の糖 尿病患者の数が 690 万人という数を見たときには大 変驚いたのですが，最近の調査では，さらに50万人 増えて 740 万人，予備軍を含めれば1620万人という 驚異的な数字になっております。まさにこの国民病 ともいえる糖尿病に対して漢方は何ができるかとい うことが問われているのですが，今日，佐藤先生か らそうしたエビデンスを含めて㧍話しいただけると 楽しみにしております。

佐藤先生のご略歴ですが，ここに書いてあります ので簡単に，といっても非常に長いのですけれども, 昭和40年名古屋大学医学部をご卒業。1 年間のイン 夕ーン終了後第三内科の大学院に入学。昭和 56 年名 古屋大学総合保健体育科学センター助教授, 昭和 62 年には同センターの教授。平成16年の 4 月に名古屋 大学名誉教授とともに愛知学院大学に籍を移されま して, 心身科学部健康科学科の教授となられており ます。ご専門は内科, 糖尿病学, 殊に運動療法, 血 管障害について。学会活動ですが, 日本東洋医学会, 日本糖尿病学会, 日本体力医学会理事のほか, 糖尿 病学会の編集委員長, また日本東洋医学会の編集委 員長として, 昨年, 『入門漢方医学』の出版にご尽 カされたことは皆様よくご存じだと思います。
私も実は内分泌の教室に抢りまして, 佐藤祐造先 生といいますと, 運動療法の大家というイメージ だったのですが, 恐らく牛車腎気丸の研究から漢方 に傾倒されたと理解しております。本日は，最近の エビデンスとともに先生のご研究の一部をご披露い ただけるということですので，楽しみにしておりま す。よろしくお願いします。

佐藤 ご紹介いただきました愛知学院大学の佐藤 でございます。東洋医学会の若手のホープというか, 第一人者の渡辺先生にご司会をたまわりまして, 大 変光栄に存じます。また，こういう教育講演の機会 をお与えいただきました石橋会長, 杉山準備委員長 に厚く御礼申し上げます。

私は，たまたま1984年に牛車腎気丸が糖尿病神経 障害に由来するしびれに効くということを，たしか 和漢医薬学会で発表させていただいて，それを「臨 床と研究」に載せたわけです。日本東洋医学会はそ のあとに入会させていただいたわけですが，入会後 ちょうど20年ということで，そのときに教育講演を させていただき, 大変光栄に存ずる次第です。

「糖尿病治療戦略と漢方」という題名ですが, 先 生方すべてが糖尿病のご専門というわけではないと 思いますので，簡単に糖尿病とその合併症について ご紹介申し上げ，それから糖尿病診療における漢方 薬の果たす役割を，私のわかる範囲内ですけれども 


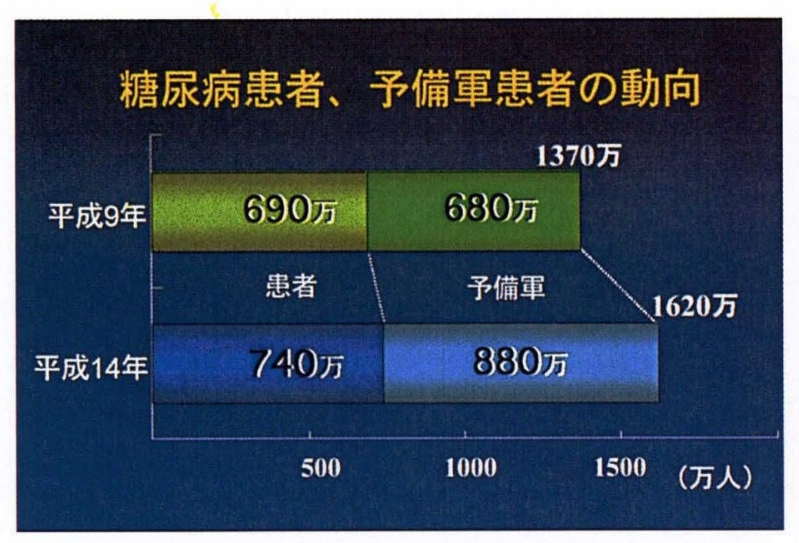

图 1

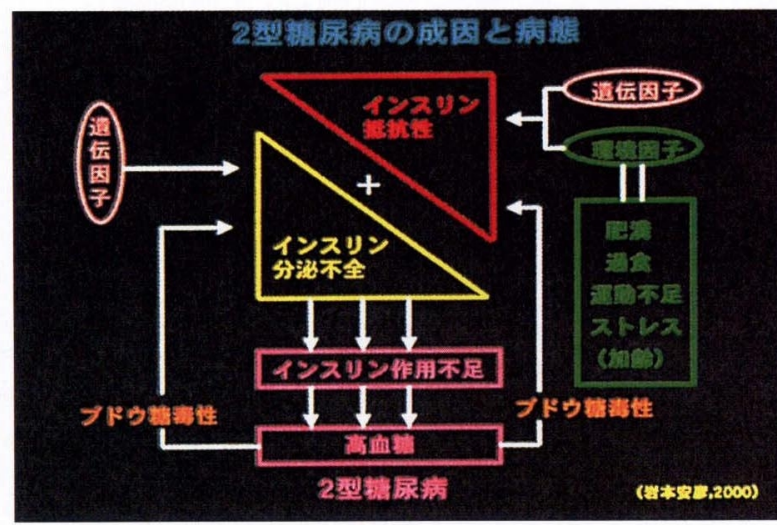

图 3

考えまして，それから，先ほどご紹介いただきまし た糖尿病神経障害の治療と漢方薬の役割ということ で, 私どもの臨床的な研究成績, それから, 名古屋 大学大学院健康スポーツ医学分野において40人ほど 学位を取得するよう指導したわけですが，その一部， 大学院生等がやってくれたインスリン抵抗性と漢方 薬に対する動物実験成績, それから最終的に結語と いうことで，糖尿病に拈ける漢方薬の適用という順 序でお話をさせていただきます。

\section{1. 糖尿病と合併症}

まず初めに，糖尿病の概要ですが，今ご紹介があ りましたように，糖尿病の患者さんは 5 年間で50万 人，予備軍が 200 万人，両方合わせると 250 万人が 5 年間で増えているということです（図１）。なぜ増 えているかということについては，食事性の要因と しては動物性のたんぱく，動物性の脂肪が多いとい うことと, それから，車の保有台数に象徴される運 動不足が関係しているわけです（図 2）。

糖尿病は,ご承知のようにインスリンが出なく なってしまう 1 型の糖尿病と，2 型の糖尿病に分類 されます。我が国で多いのは2 型の糖尿病ですが,

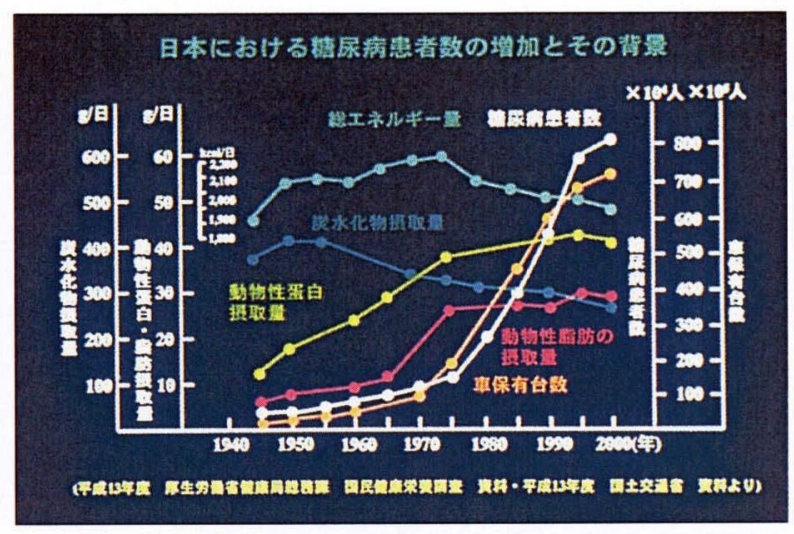

図 2

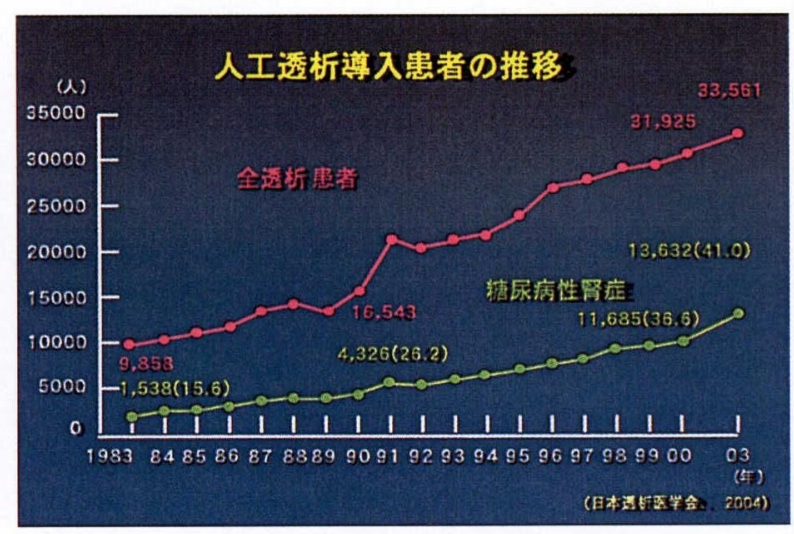

図 4

2 型糖尿病の場合には，インスリン分泌の低下とイ ンスリン抵抗性がいろいろな割合で起きてきます。 インスリン分泌低下というのは遺伝的な要因が大き いのですが，インスリン抵抗性に対してはいろいろ な生活習慣要因が関係しています（図３）。

私は，糖尿病の分野では糖尿病の運動療法という ことで運動によるインスリン抵抗性改善を中心に研 究させていただいているのですが，私どもの動物実 験成績で幾つかの漢方薬でこのインスリン抵抗性を 改善させることができるというエビデンスを見いだ しています。そうしますと，後ほど申し上げますが， 漢方薬を投与することによって糖尿病の治療ができ る，さらには予防ができるということになるわけで す。

糖尿病は大変恐ろしい病気で, 網膜症では, 年間 3500 人ぐらい糖尿病で失明します。

先週日本透析学会がありました。透析に関する集 計結果を名古屋大学の腎臓研究室の湯沢講師から教 えていただきましたが，新規の導入患者さんがどん どん増えています。その中で, 糖尿病性腎症に基づ くものが実に $41 \%$ 。3 年前に比べて，比率，絶対值 


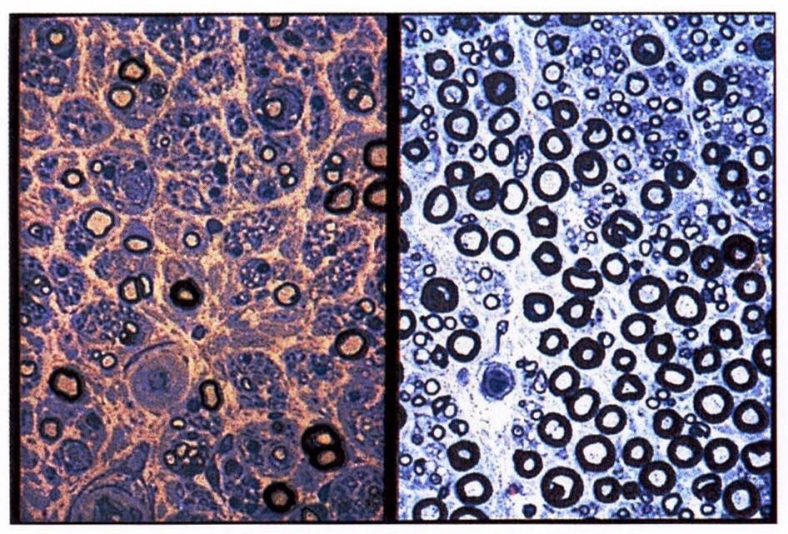

图 5

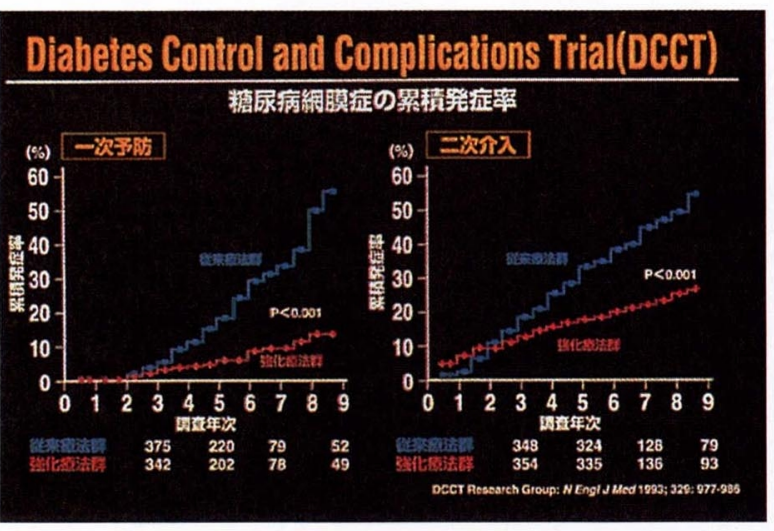

図 7

も非常に増えています（図４）。透析医療というの は，一人 550 万以と600万円とも医療費がかかると いうことが言われていますので，やはり少しでも透 析導入を減らすようにするということが大切だと 思っています。

このスライドは糖尿病神経障害の神経生検所見で す（図 5 )。コントロールに比べて糖尿病の患者さ んでは明らかに大口径線維が減っているということ がお分かりいただけると思います。

もう1つは，神経の血管 (vasa nervorum) ですが, 非常に壁が厚くなって, 内腔が狭くなっているとい う所見です。すなわち, 高血糖に基づく代謝異常に よって神経線維そのものがやられる，もう一つは神 経の血管がやられる。したがいまして, 糖尿病性神 経障害の治療には, 高血糖の是正と, 血管を広げる, 神経の虚血を是正することが必要になるわけです。

糖尿病では脳動脈硬化（脳卒中）や糖尿病性壊疽 もおこります（図6）。このように，糖尿病は頭の 先から足の先までどこに合併症が起きるか分からな い，大变恐ろしい病気だということがお分かりいた だけると思います。

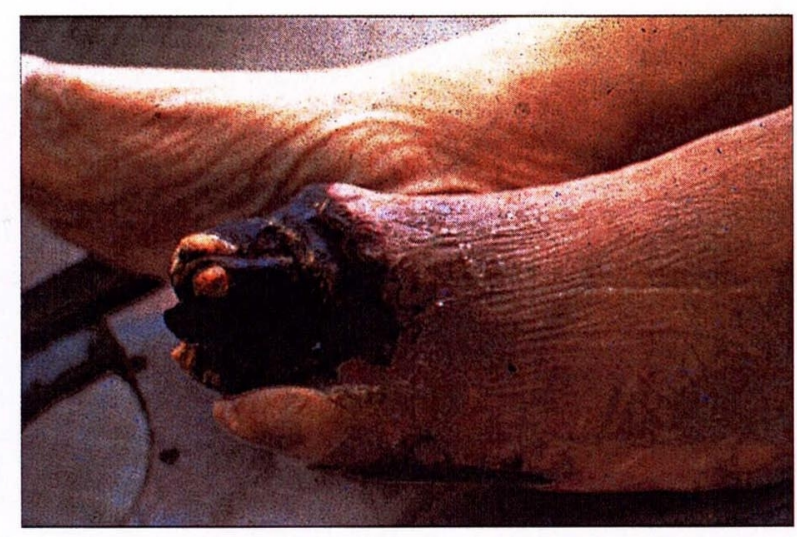

图 6

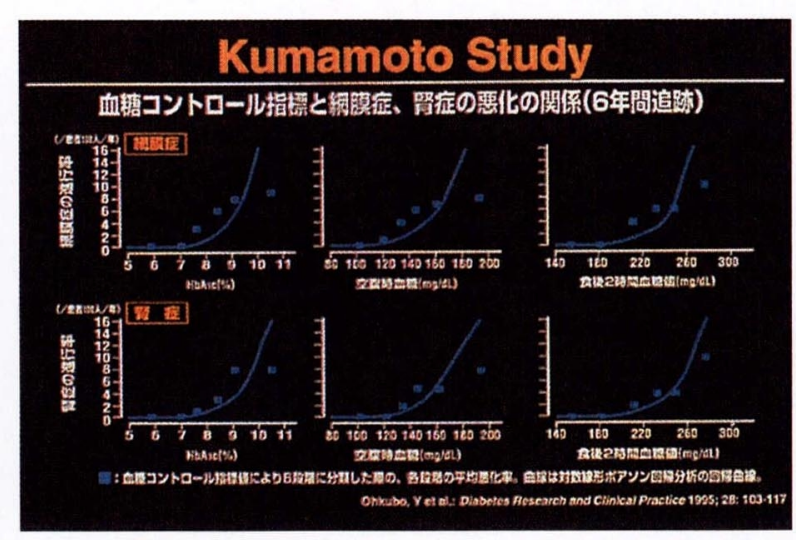

図 8

糖尿病に対してはいろいろな大規模研究が行われ ており，これは 1 型糖尿病に対してのアメリカの研 究で, 従来型のインスリン治療よりは血糖コント ロールを非常に厳密に行う, 強化インスリン療法で は明らかに糖尿病の合併症の起こり方が少ないとい うことが明らかになっています(DCCT 研究) (図 7 )。

Kumamoto Study は七里名誉教授が熊本大学で行 われた研究です。 2 型糖尿病に対して 1 日 4 回イン スリンを射つということですが, やはり血糖值が高 い, それからへモグロビン A $1 \mathrm{c}$ が高い症例に網膜 症, 腎症が多いということが分かっています（Kumamoto 研究)。したがいまして, 高血糖が原因で ある, 高血糖の是正が大切であるということがお分 かりいただけると思います（図８）。

まとめますと, 糖尿病神経障害の場合には, 高血 糖が問題である。高血糖でなぜ問題があるかといい ますと，たんぱく質が糖化する， Glycated protein が できます。また, ソルビトール代謝経路の元進や, ミオイノシトールの細胞内取り込みが減少します。 さらに，先ほどの神経組織のバイオプシーの標本で も見ていただいたと思いますけれども, 虚血が関係 
表 1

\section{糖尿病性神経障害の成因}

高血糖による機能性蛋白の糖化促進

2. 高血糖に直接付随する代謝異常,

a) ソルビトール代謝経路の亢進

b）ミオイノシトールの細胞内取り込みの減少

，糖尿病性細小血管障害による神経組織の虚血

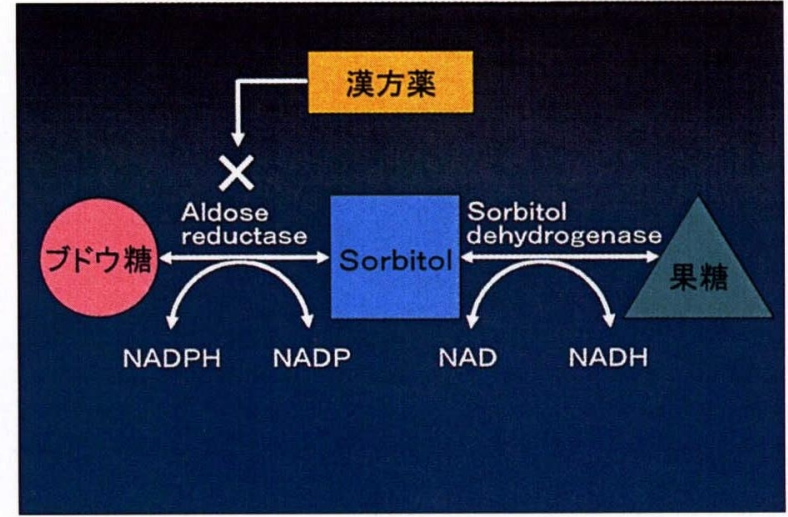

图 9

\section{します（表 1 )。}

糖化たんぱくの代表例です（表 2 ）。へモグロビ ン Alc は現在血糖のコントロールの指標に使われて います。このようにいろいろたんぱく質が変性しま す。そして, 糖尿病で妊娠異常が起きることはよく 知られていますが，胎盤のコラーゲンが変化する。 したがって，胎盤の機能が低下していろいろなこと が起きてくると考えられています。

これはポリオール経路の説明ですが（図９），血 糖值が非常に高くなる。ですから, 空腹時血糖が180 以上というょうな高い状態ですと, アルドーズ還元 酵素というものが働き，ソルビトールができます。 ソルビトールというのは細胞膜を通しません。ソル ビトールがどんどんできると，浸透圧が非常に高く なり, 細胞膜を破壊する。さらには析出してきて, それで細胞を破壞するということになるわけです。 ですから，この経路をシャットアウトするというこ とが一つの治療法になります。

したがいまして，糖尿病の治療ですが，とにかく 高血糖を治すということが大切です。しかしながら， 私の患者さんでもなかなかよくなりません。そのよ

\section{表 2}

\section{代表的な糖化蛋白}

1) ヘモグロビン (RAHBAR, 1968)

2) コラーゲン（関節・胎盤・皮覻・腎・腱 大動脈・冠動脈・神経・肺) (ROBINS, etal, , 1976)

3）赤血球細胞膜蛋白 (BAILEY，etal，1978)

4) 水晶体蛋白 (STEVENS, etal. , 1978)

5) 血漿蛋白 (MCFARLAND, 1984)

6) $\mathrm{LDL}$ アアポ蛋白 (WTTZUM, ef al. , 1984)

7) 酵素蛋自

\section{表 3}

\section{糖尿病性神経障害の治療}

1. 高血糖の是正

a) 絶対的あるいは相対的インスリン不足の解消

b）末梢組織におけるインスリン抵抗性の改善

2. 高血糖に伴う代謝巽常の是正

a) ソルビトール代謝経路のプロック

3. 神経内虚血の是正

4. ビタミン製郕の投与

5. 自覚症状軽減の為の対症療法

うなときには, ソルビトール代謝経路をブロックす るというのも一つの対処方法です。また，虚血を是 正するということも大切です。ですから，高血糖を 是正する, それからソルビトール代謝経路, 虚血の 是正ということです（表 3 )。

血糖值の是正，すなわち糖尿病の治療方法ですが， 食事療法，運動療法というのは非常に大切で, 運動 することによってインスリン抵抗性を改善させ，そ れからもちろん食後の血糖值が急に上昇するという ことを防ぐこともできます。食事も，適度に制限す るということが大切です。

しかしながら，インスリン分泌能が低下している 場合には，患者さんはそういうときには，「もう一 週頑張ります」とか「もう一月頑張ります」という ようなことをおっしゃられますけれども，幾らまじ めに食事療法をやる，運動療法をやっても，血糖コ ントロールが良好にならない場合には，㧍薬を用い て，血糖值の改善を図るということです。

我々が医師になったころには，SU薬とビグアナ イド薬だけでしたが, 最近はインスリン抵抗性改善 薬や $\alpha$ グルコシダーゼ阻害薬, さらには, グリニ 


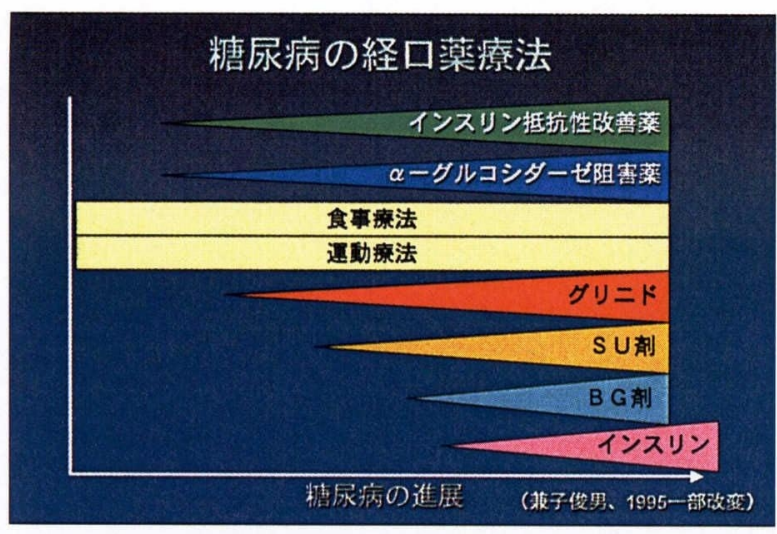

図10

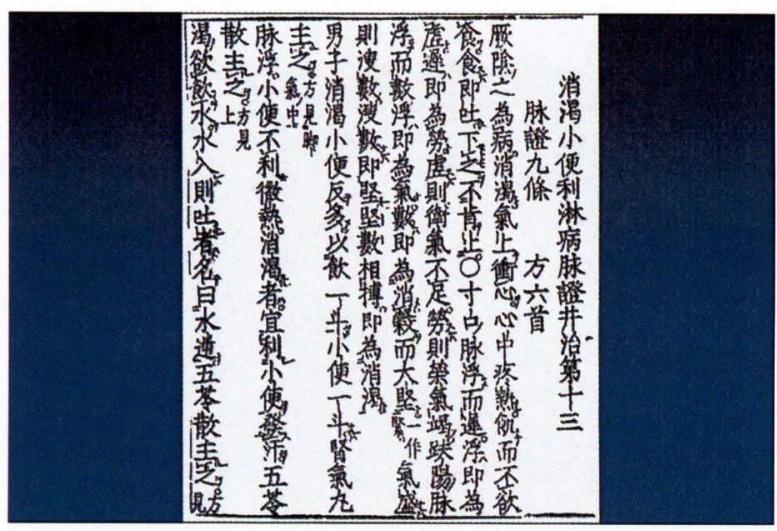

图11

ドというのは，まだ一月前ぐらいにも新しい「ミチ グリニド」というものが従来の「ナテグリニド」に 加えて発売されましたけれども，いろいろな薬剤が 市販に供されています (国10)。

ということで，血糖值の是正を図るということが 必要ですが, 経口血糖降下薬でよくならないときに はインスリンを使うこととなります。もちろん 1 型 糖尿病のときには始奴らインスリンを使います。 いずれにしても，このような原則は現在のところ必 ず守らなければならないと思います。

\section{2 . 糖尿病診療における漢方薬の果たす役割}

そこで，糖尿病診療における漢方薬の果たす役割 ということで，私の考え方を申し上げたいと思いま す。

これは，湯原先生が以前に提示されたものを少し リバイズしたものですが，やはり診断の段階，それ から治療の段階でも基本的に血糖を重視するという ことは必要です。今申し上げましたように，血糖值 を下げるには，いろいろなお薬のほかにインスリン がある。さらには，このようないろいろな対症療法 がある。さらには，アルドーズ還元酵素の阻害薬
表 4
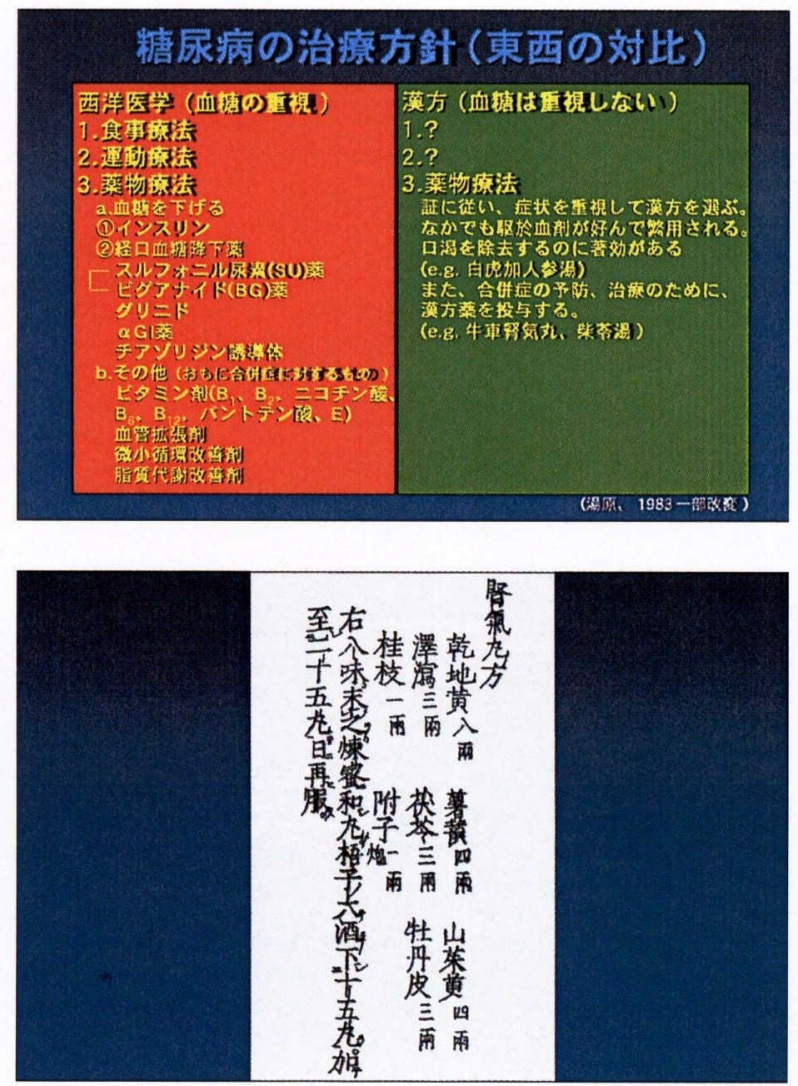

图12

（ARI）というものもあるわけです。

しかしながら，それではなかなかうまくいかない という実例も多いわけで，そういう場合には，ここ に書いてありますように，証に従い，症状等も重視 して，いろいろな薬方を選ぶ。駆㾉血剤なども使わ れますし，白虎加人参湯などは口渇を除去するのに も効果があります。それから，合併症の予防治療の ために漢方薬を投与する。例えば牛車腎気丸のよう なものを投与するということです。ですけれども， やはり血糖值を重視するということは大切です

(表 4 )。

張仲景先生がもともと報告された本がありました のでスライドにしましたが，漢方の古典によります と, 糖尿病につきましては, 「男子消渴，小便反多， 以飲一斗，小便一斗，腎気丸主之」ということが書 いてあります（図11）。証は当然のことながら重視 しなければなりません。これは腎気丸という薬方で すが現在八味地黄丸として使われているものです。 ということで, 古典に記載されています（图12）。

エキス剤を使って実施しました私どもの治験成績 をご紹介させていただきたいと思います。 


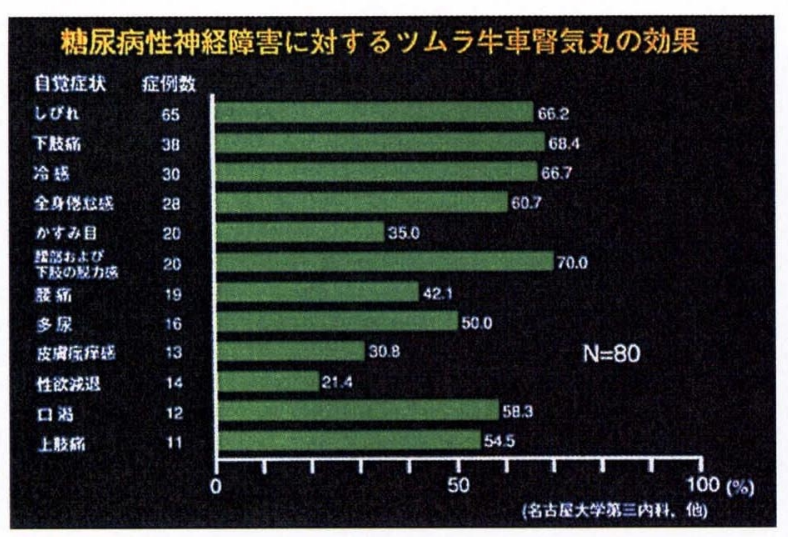

図13

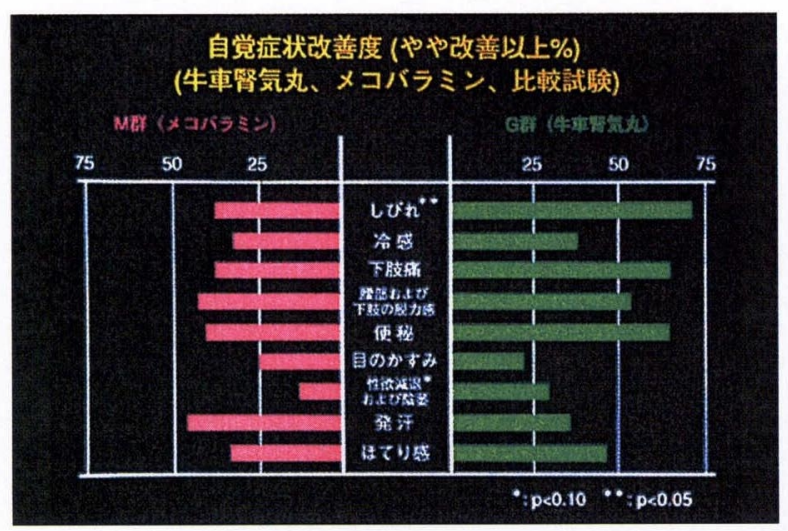

图15

\section{3．糖尿病神経障害の治療と漢方薬の役割}

先ほどの腎気丸（八味地黄丸）に牛膝と車前子を 加えた 10 種類の生薬が入っております牛車腎気丸を 糖尿病神経障害を有する症例に投与しました。この 結果は1984年に「臨床と研究」，それから「和漢薬 学会雑誌」にも掲載されています。糖尿病神経障害 の患者さん 80 例に牛車腎気丸のエキス剂を 12 週間以 上投与して，自他覚症状，臨床検査成績を比較しま した。

80例の自覚症状の集計ですが（図13）,80例の中 でしびれを訴えられた方が65例いらっしゃいました。 それらの方に対する有効率が $66.2 \%$ ということでし た。その後，たまたま神経治療学会のシンポジウム で大澤仲昭先生が司会をされ，私がシンポジストを つとめさせていただいたことをきっかけに，私ども がいちばん初めに報告させていただいてから10年後 の1995年までの国内の成績をまとめてみました。

そうしますと，554例報告例がありましたが，そ の中でしびれについての有効率を見ると， $67.3 \%$ と いうことでした。ですから，我々がいちばん最初に 報告させていただいたものが $66.2 \%$ ，そして全国集

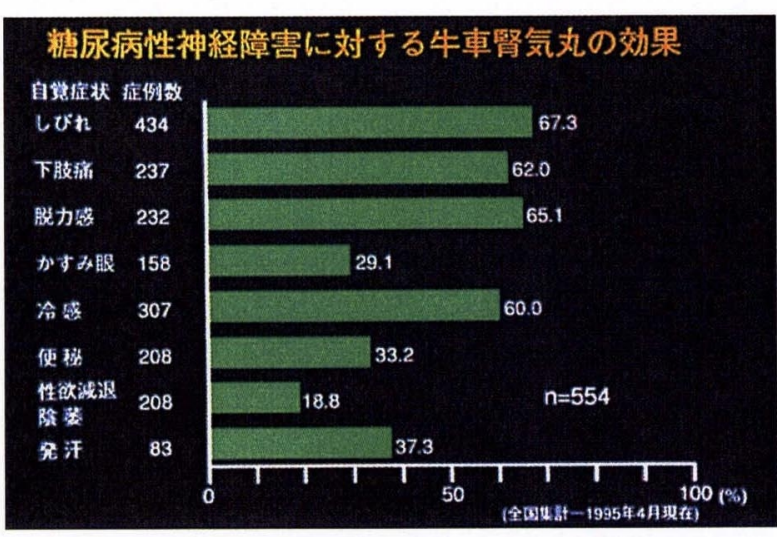

図14

\section{表 5}

牛車腎気丸の構成生薬の薬理作用

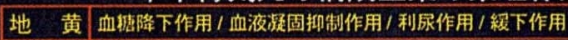

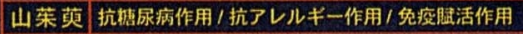

山薬男性ホルモン增强作用

沢 㴓利尿作用 / 抗脂肪肝作用/コレステロール血症の改盖作用

沢 澫 血液瀑固抑制作用

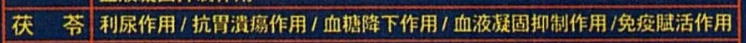

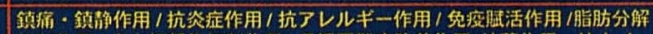

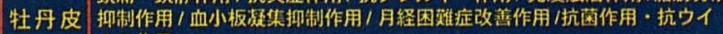
ルス作用

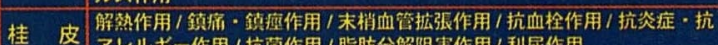

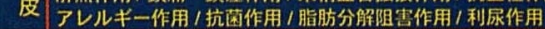

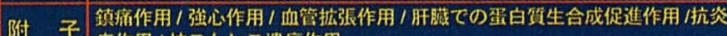

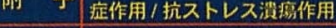

車前子 インターフェロン診起作用/利尿作用

牛腅抗了レルキー作用/利尿作用

計, 症例がおよそ7倍ぐらいに増えたわけですが, ほぼ同様の $67.3 \%$ ということですので, 我々の報告 はそれなりの信頼性があるというか，デフィニット なものであろうと思っています（図14）。

話は前後しますが，先ほどの84年の成績を得て， 少し西洋薬との比較試験を行おうということで，メ コバラミンとの比較を行いました。これは, 北は東 北大学からずっと南は琉球大学まで, 何人かの糖尿 病専門の先生に加えて, さらには神経内科専門の先 生, それからコントローラーとして統計学者も入っ ていただきまして，封筒法というのは今の時点では あまり信頼できない方法だそうですけれども，今日 の午前中のチェン先生の括話でも，生薬の場合には ダブルは難しいというような, 本当のプラセボは難 しいというようなお話もありましたが，その時点で はとりあえず封筒法で行いました。そうしますと，

しびれに対しまして，牛車腎気丸はメコバラミンよ りも5\%未満の危険率で有意に有効性が高いという ことが判明しました（図15）。

それを,「糖尿病」(日本糖尿病学会雑誌), 最近 私はこの雑誌の編集委員長をさせていただいており 


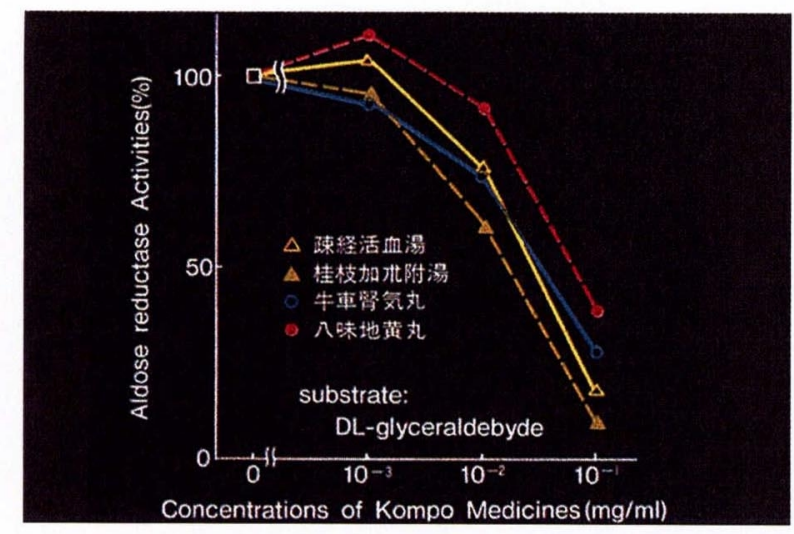

図16

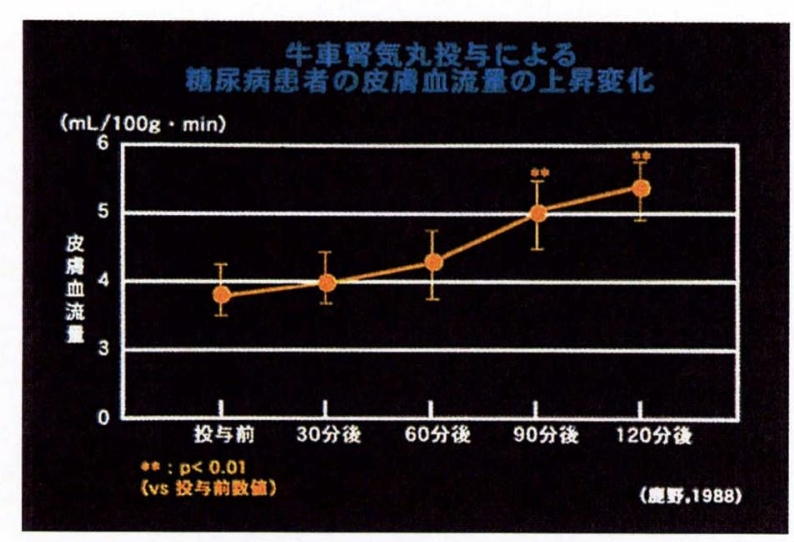

図18

まして, 最近はかなりやさしくなったというか, $70 \%$

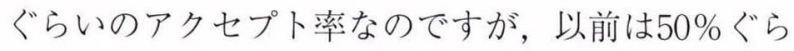
いというところだったのですけれども，一応「糖尿 病学会雑誌」に掲載されました。

87年ですが，その時点で有効性のメカニズムに関 して, 構成生薬から考えてみて, やはり作用機序を 書かないと雑誌にアクセプトされないということで, 考えてみました（表 5 )。構成生薬には血糖降下作 用があるものが幾つかあるわけですし，それから， 脂質代謝が改善するという薬物も含まれており， 我々としてはとにかく神経組織に代謝異常があり， この薬物は何らかの意味で代謝異常を是正する力が あるだろうと推測しました。

それから, 血糖降下作用について, 我々の印象で はあまりないと思っていましたが，最後に紹介させ ていただきますけれども，70例ばかり患者さんに投 与して, 従来の治療法, 2 型の糖尿病に牛車腎気丸 を投与しましたところ，空腹時血糖が有意に下がり ましたので，血糖降下作用もあると考えています。

いずれにしましても，代謝改善作用がある。それ から血液凝固，血小板凝集抑制など，そういうもの

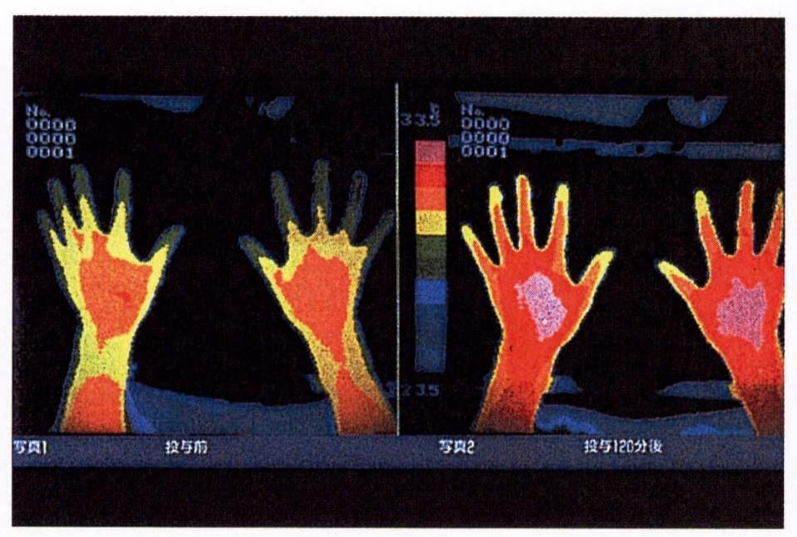

図17

を改善する作用がある。さらには, 血管の拡張作用 があるというようなことも構成生薬の作用として書 かれています。

そういうことから考えまして, 考察のところに， 神経の代謝を改善させる, それから血液凝固や血管 拡張作用ということからいって, 恐らく神経の血行 も改善する作用があるだろうということを述べたわ けです。

そうしますと，それに対するエビデンスが，山梨 医大の女屋教授，もう退官されましたが，アルドー ズ還元酵素を牛車腎気丸をはじめ 4 種の漢方薬が有 意に抑制するというデー夕を発表されたわけです

(図16)。したがいまして，先ほどのブドウ糖から ソルビトールができるのが，アルドーズ還元酵素を 使って抑えることができる。ですから，これはエパ レルスタットというものが今市販に供されているわ けですが，それと同じような作用があるということ です (図 9)。

また，現在藤田保健衛生大学にいらっしゃいます 鹿野助教授が大垣市民病院にいらっしゃったときの 成績ですが, サーモグラフィで観察しますと, 牛車 腎気丸の投与により,明らかに皮膚温が上昇する(図 17)。さらには皮虐の血流量が増えるということが 分かりました（図18）。

次に, 血管拡張のメカニズムに関して, 最近の動 物実験成績で, 鈴木先生らは, 牛車腎気丸を使うと 明らかにラットの血流量が増える。アトロピンより もむしろ明らかによく増えるということですが, NO の合成阻害薬である L-NMMA というものを一緒に 入れますと, 牛車腎気丸による皮膚の血流の増加作 用がほとんど完全に消失するということを報告して 䚷られます。したがいまして，やはりこの皮膚の血 


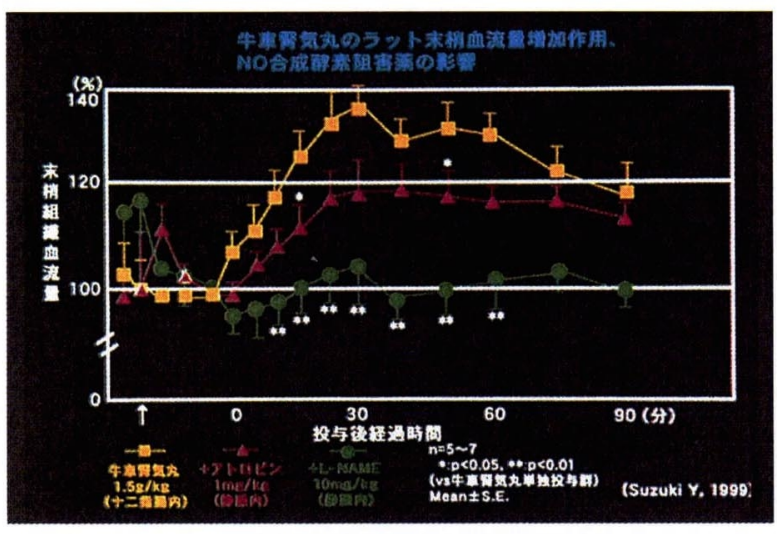

図19

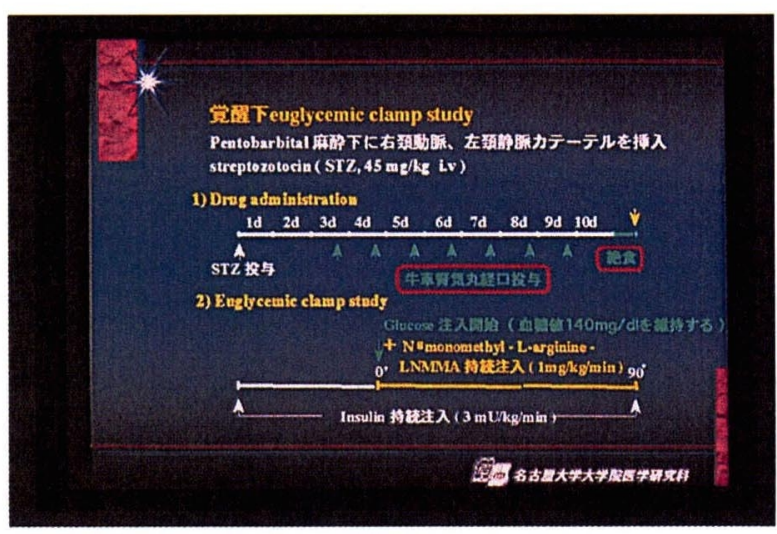

図21

管の拡張というのは, 恐らくはNO が関与している だろうということです（图19）。

さらに，鎮痛作用があるというのは，附子の作用 ですが，そのことにつきましても幾つかの研究が行 われており, 星薬科大学の亀井先生や, 鈴木先生ら の成績によりますと, 麻薬などよりもむしろ明らか に鎮痛作用があるというようなエビデンスも見い出 されています。

したがいまして,牛車腎気丸に関しましては, 1000 年ぐらい続いている処方ですけれども，及ばずなが ら私どもは新しい適用，こういう患者さんによく効 くということを，1984年，20年前に報告させていた だいたわけです。それに対して，そのメカニズムは， その時点では単に推定したにすぎなかったわけです が, 明らかな客観的なエビデンスが第三者から出て きまして，メカニズムの解明も行われているという ことになるわけです。

\section{4. インスリン抵抗性と漢方薬：動物実験的研究}

糖尿病神経障害は非常に重要な課題です。それに 対して牛車腎気丸が臨床的に有効ですけれども，イ ンスリン作用に関しては報告がないということで,

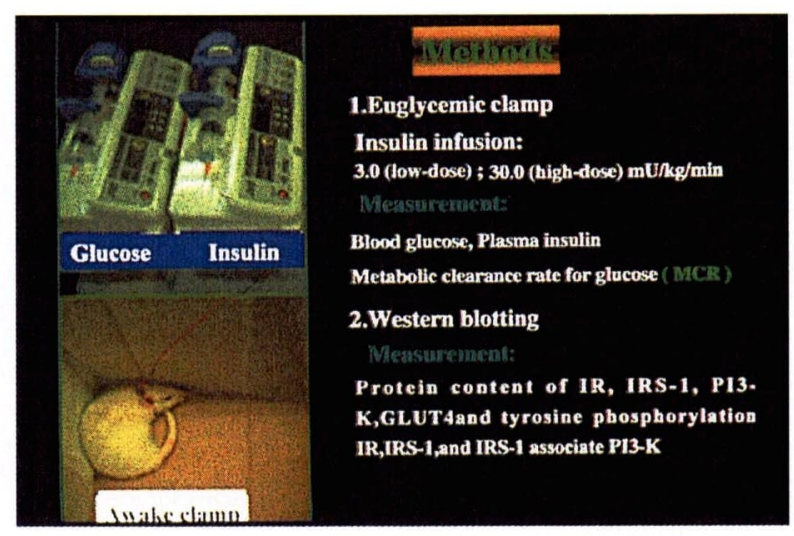

図20

$\mathrm{STZ}$ 糖尿病でストレプトゾトシンというのは膵臓 のベー夕細胞を破壊して糖尿病を起こすわけですが, STZ 糖尿病に起因するインスリン抵抗性が牛車腎 気丸でよくなるかどうか，その作用について NO が 関与するかどうか，さらにはインスリンシグナルパ スウェイはどのように関与しているかということに ついて検討を加えました。

NOについて考えましたのは，先ほどのような報 告, 血管との関連もありますし, 我々は Cペプタ イドの研究をスウェーデンのカロリンスカ研究所と 共同研究をやっておりまして，それにも NOが関与 しているということで, NOの関与を調べたわけで す。

私はヒューマンについてはスウェーデンのカロリ ンスカ研究所で DeFronzo 博士から直接教えていた だいてきたのです。動物実験的な方法は，オースト ラリアの Garvan 研究所の Kraegan 博士らが行って いる方法で, 完全に覚醒下で, 要するに普通に生活 している状態でグルコースクランプを実施します。 インスリンの注入量は 2 段階で,最終的には molecularメカニズムについて, Western blotting を用いて 実施しています。

これがその投与方法等についてですが，実験を行 う 1 週間前にペントバルビタール麻酔下で頸静脈, 頸動脈にカテーテルを扦入し, 静脈よりストレプト ゾトシンを注入して糖尿病ラットを作成します（图 20)。

牛車腎気丸を単回投与の場合と 1 週間投与した場 合と，両方やっています(図21)。さらには，NO の合成阻害薬である NMMA というものを入れると どうかという検討も加えています。これはなかなか できない方法で, 大学院生が入学してこられると, 


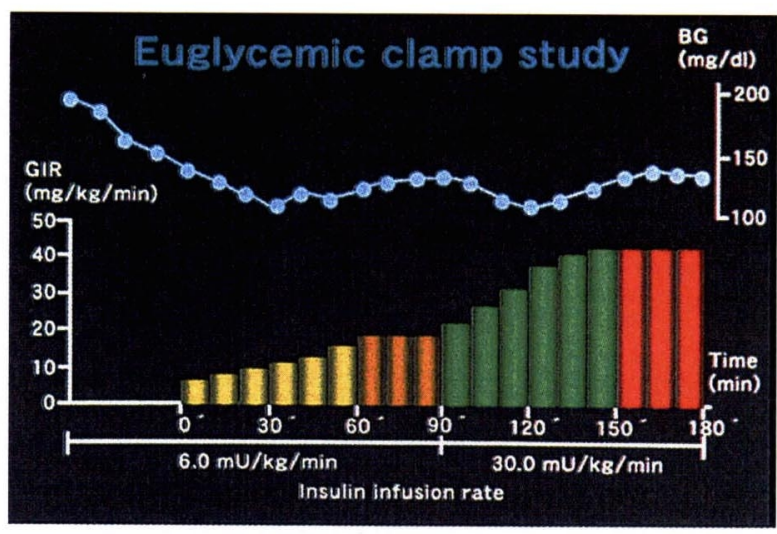

図22

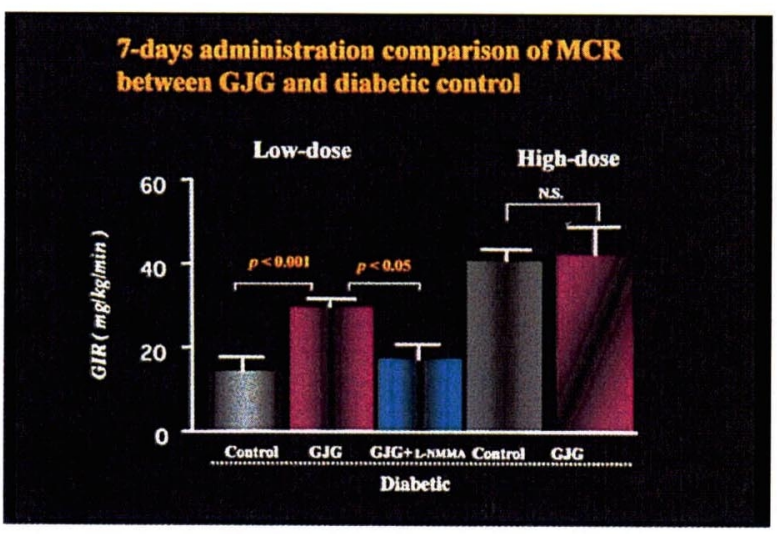

図24

次々と技術の伝承を図っています

方法は, インスリンを持続注入すると, 当然血糖 值が下がる。これは STZ 糖尿病ラットですので血 糖值が少し高くなっています。それを $140 \mathrm{mg} / \mathrm{dl} く ゙$ らいに下げる。コントロール群のラットでしたら 90 $\mathrm{mg} / \mathrm{dl}$ 位のレベルに維持します。インスリンの注入 量を一定にして，血糖值が低下するのに対してブド ウ糖を注入し，血糖值を空腹時のレベルに維持しま す。ですから，インスリンに対する反応性がよけれ ば，たくさん血糖值が低下する。したがって，ブド ウ糖もたくさん注入されるということで，注入ブド ウ糖量（GIR）が末梢組織のインスリン感受性を表 します。この方法は末梢組織のインスリン感受性を 評価する方法のゴールドスタンダードといわれてい

\section{る方法です (図22)。}

1979年に，ちょうど私がスウェーデン・カロリン スカ研究所に留学していたころなのですが,「Am J Physiol」に報告された方法です。私は名古屋大学大 学院で 40 人の方に医学博士を取得していただきまし たが，何人かは，この方法を用いており，つい最近 4 月にも一人この方法を用いた研究で取得していま

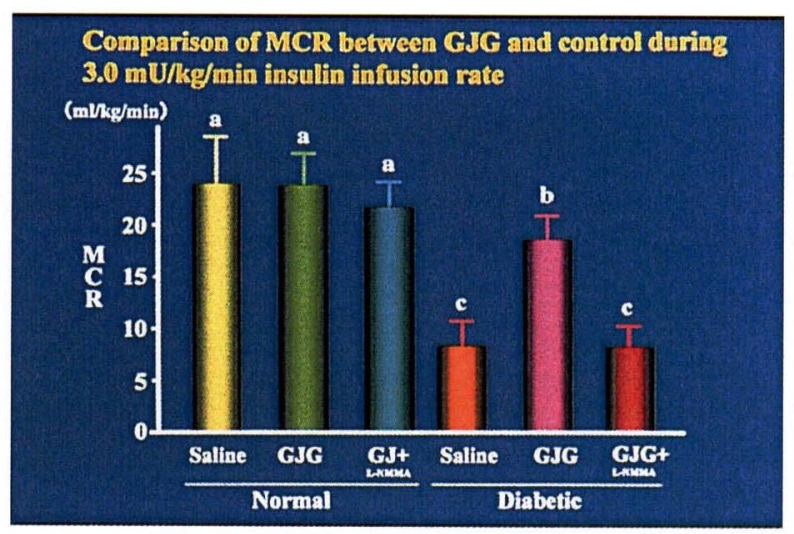

國23

す。非常にいい方法ですが，これをラットに応用し， しかも無麻配覚醒下の状態で行っています。ちなみ に，麻酔下の条件ですとストレスが負荷され，かな り GIRが下がります。

4 種類の漢方薬を用いて, グルコースクランプを 行い, GIRの変動を観察しました。水を入れるだけ でも少しはそれが刺激になって GIR は低下するの ですけれども，しばらくすると回復します。大柴胡 湯は，最終的には GIR が少し増えるのですが，か なり低下します。牛車腎気丸も，始めはちょっと低 下するのですが，かなり回復します。清心蓮子飲は あまり戻らないというところです。この方法で60～ 180分の GIR を平均しますと, 牛車腎気丸は明らか に短期的にもインスリン抵抗性を改善させる。ほか のものについてはあまりよくないということです。

興味深いことに，コントロール群ラットに牛車腎 気丸を投与しても GIR は変動しません。コントロー ル群でL-NMMAを一緒に入れてもあまり変わりが ありません。STZラットでは GIRが明らかに低下 します。低下したGIRに対して牛車腎気丸を投与 すると明らかに回復します。しかし，L-NMMAを 入れると，その効果がなくなるという結果になりま した (図23)。

長期投与というわけでもありませんが，牛車腎気 丸を 1 週間投与した結果です。この研究での正常血 糖クランプ法のインスリンの注入量は少量と大量に していますが, low-dose clampの場合に, 明らかに 牛車腎気丸, これはコントロールといっても STZ のコントロールですけれども，生食だけを入れたも のに比べると, 明らかに牛車腎気丸を入れたもので は回復する。回復するわけですが，L-NMMAを入 れると低下するということです。high-doseのほう 


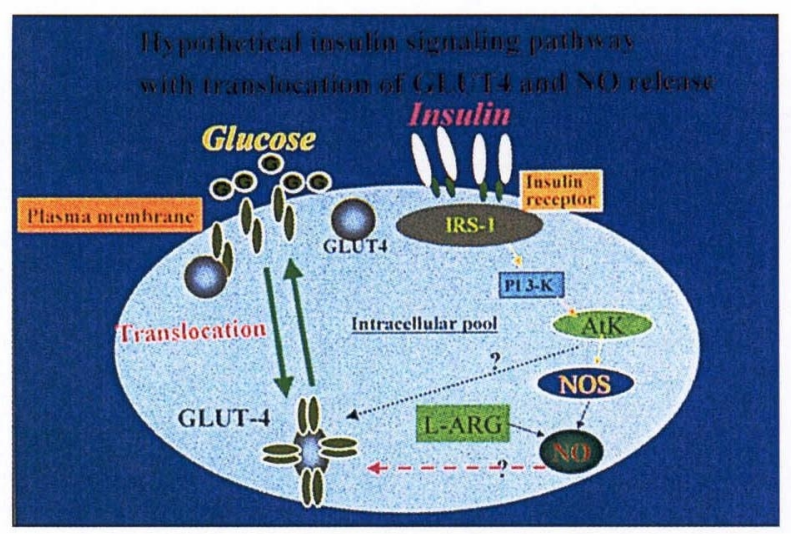

図25

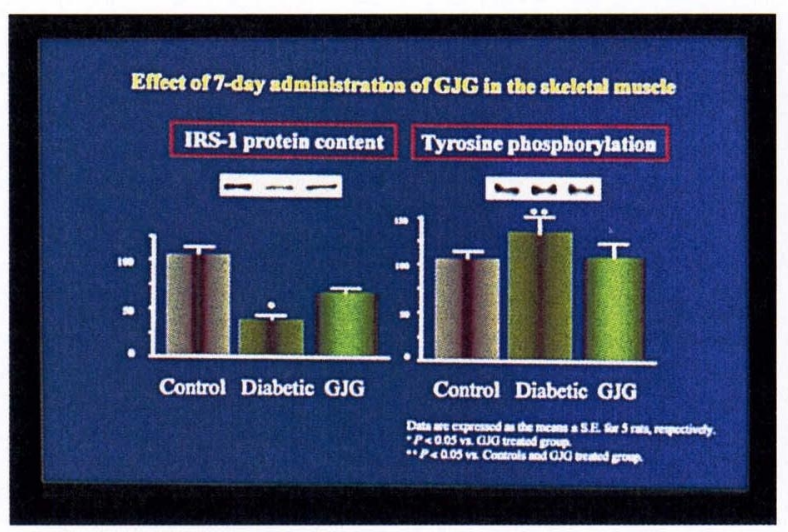

図27

ではどうもその効果が出ないということになってい

\section{ます（図24）。}

ということから考えてみますと, STZ糖尿病ラ ットにおいて，牛車腎気丸は生理的なインスリンレ ベルにおける末梢組織のインスリン抵抗性を改善す る。この改善効果は, L-NMMAの投与により抑制 されたことから，そのメカニズムとしてNO 合成酵 素を介した効果であることが示唆されたということ です。

先ほどの研究は名大病院総合診療部佐藤寿一講師 が指導して，胡暁晨先生が実施されました。その後 秦柏林先生が来られてから，インスリンシグナル伝 達経路にも検討を加えました。

インスリンは, レセプターについで IRS 1 や PI 3 カイネースなどを介して, 最終的に糖輸送担体 GLUT 4 が細胞表面にトランスロケーションをする， それから長期になるとたんぱく量が変化するという メカニズムで，ブドウ糖の取り込みが促進されると いうメカニズムになっています（図25）。

牛車腎気丸を投与した場合の骨格筋の変化を見て みますと, インスリンのレセプターのベータ部分,
Brfect of 7-day administration of GJG in the skeletal musele

IR- $\beta$ proteincontent Tyrosine phosphorylation

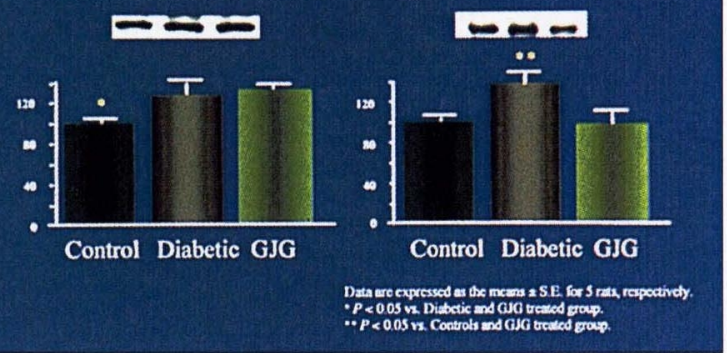

図26

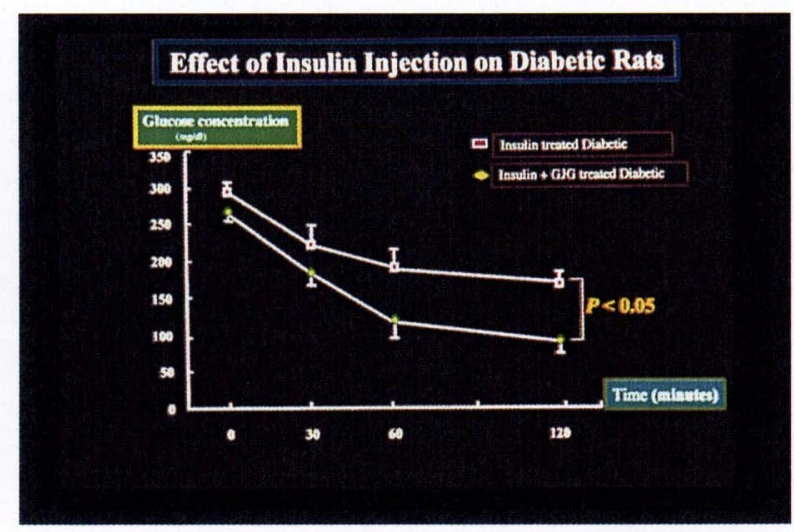

図28

要するに細胞内に入っているところのたんぱく量が, $\mathrm{STZ}$ 糖尿病にすると増えるのですが，それに対し てはどうも牛車腎気丸は効果はない。ただ，チロシ ンのリン酸化に対しては, 糖尿病で立進しているの が牛車腎気丸を投与すると正常化するというか，異 常を是正するという効果があります（図26）。

IRS 1 に関しましては, 今度は糖尿病で明らかに たんぱく量が低下しますが，牛車腎気丸を投与する と, 少し回復してくるということが判明しました。 それから, チロシンのリン酸化に関しても, 糖尿病 で増えるのですが，正常化するという現象が観察さ れました。ということで，インスリンシグナル伝達 経路もある程度は関与しているということが分かり ました（図27）。

インスリン抵抗性が改善されるのならば, インス リンを同時に注入したら当然血糖值が下がらなけれ ばいけないわけです。これも秦柏林さんがやりまし たが，インスリンを少し入れますと（インスリン感 受性試験：インスリントレランステスト）牛車腎気 丸群の血糖降下度が大でした（図28）。つまり，牛 車腎気丸がインスリンの作用をポテンシエートする 


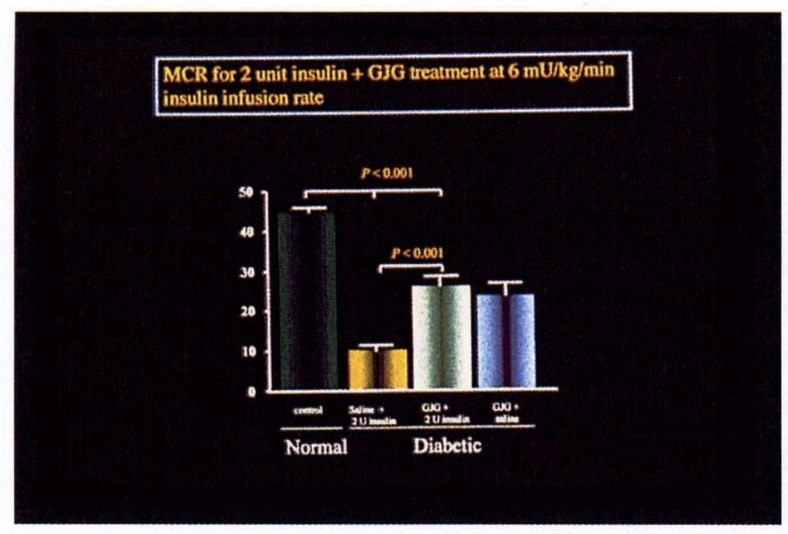

図29

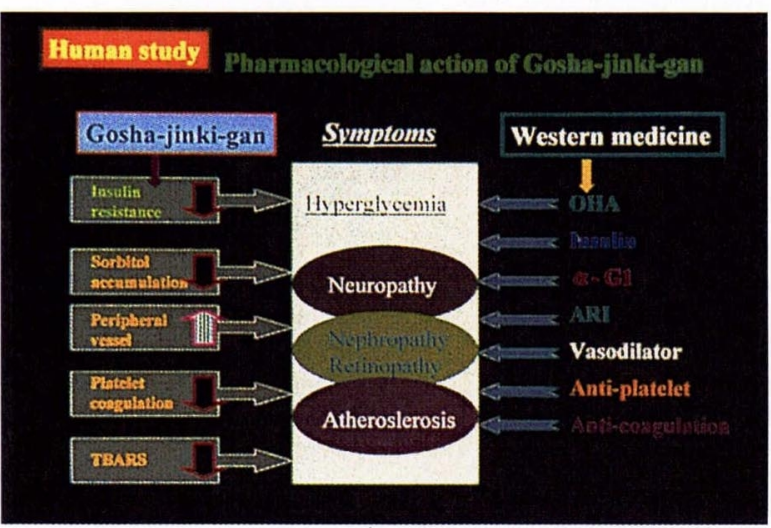

図31

ということが分かりました。

また，インスリン感受性（MCR）も明らかに回 復するわけですが，インスリン単独ではあまり増え ないわけですから，やはり牛車腎気丸がインスリン 抵抗性を改善させるのに大きな要素になっていると 思います (図29)。この点に関しましては，明日の 午後, 内分泌のところで, モレキュラー・メカニズ ムについて秦柏林先生が口頭発表いたします。

ということで，牛車腎気丸は明らかにインスリン 抵抗性を改善させる，そのメカニズムとして NOが 関与しているということです。

ヒューマンスタディもやりたいと思っていたので すが，なかなか実現しなかったのです。宇野智子先 生という中部労災病院の女医さんに行っていただき ました。現在は愛知学院大学保健センター講師に なっておられます。2 型糖尿病の患者さんに対して, 牛車腎気丸7.5g を毎食前に 1 力月間投与して，投 与前後で HOMA 指数，これもインスリン抵抗性を 表すわけですけれども，この指数を用いて検討を加 えました。HOMA-Rの計算方法は空腹時血糖 $(\mathrm{mg} /$ $\mathrm{dl}) \times$ 空腹時血中インスリン $(\mu \mathrm{U} / \mathrm{ml}) / 405$ ず。正

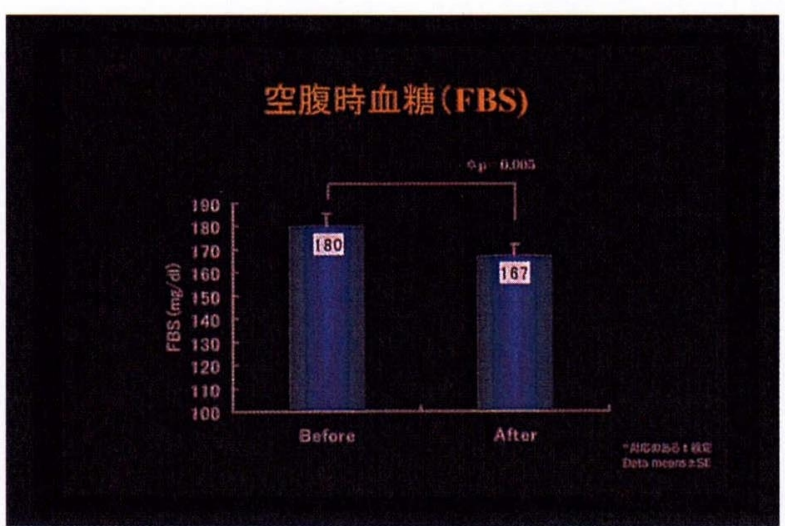

図30

常は 1 とか 2 なのですが，インスリン抵抗性がある とその数字が多くなる。ですから, 数字が下がると いうことは，インスリン抵抗性が改善したというこ とになるのです。空腹時血糖值が，そのほかの治療， 例えば経口血糖降下薬や食事療法, それは変えてい ないわけですので，牛車腎気丸を投与することに よって，明らかに空腹時血糖が改善しています（図 30)。

それから，HOMA-R も改善します。牛車腎気丸 を中止しますと，また元に戻るということも確認し ています。先ほどの動物実験的研究はすでに「Diabetes Res Clin Pract」とか幾つかの雑誌に通ってい るのですが，このヒューマンスタディーはまだ現在 リバイズ中です。

8 名の糖尿病患者さんには, グルコースクランプ を行いました。ラットの成績と必ずしも合わないの ですけれども, 薬理学的インスリン濃度下でインス リン抵抗性を改善させるということが分かっていま す。

以上，牛車腎気丸投与で HOMA-R が改善し，総 コレステロール，中性脂肪は，投与前後で有意に低 下しました。それから，この GIR というのはイン スリン抵抗性のグルコースクランプ法によるブドウ 糖の注入量ですが，牛車腎気丸投与後上昇傾向を示 し，特に high-dose clamp では有意に増加したとい う成績が得られています。

まとめますと，牛車腎気丸はラットを用いた動物 実験で明らかにインスリン抵抗性を改善させます。 それには，インスリンのシグナル伝達経路や NO が 関与しているということです。それから，牛車腎気 丸が 2 型糖尿病の成因であるインスリン抵抗性を改 善させるということは，糖尿病の合併症の予防，治 


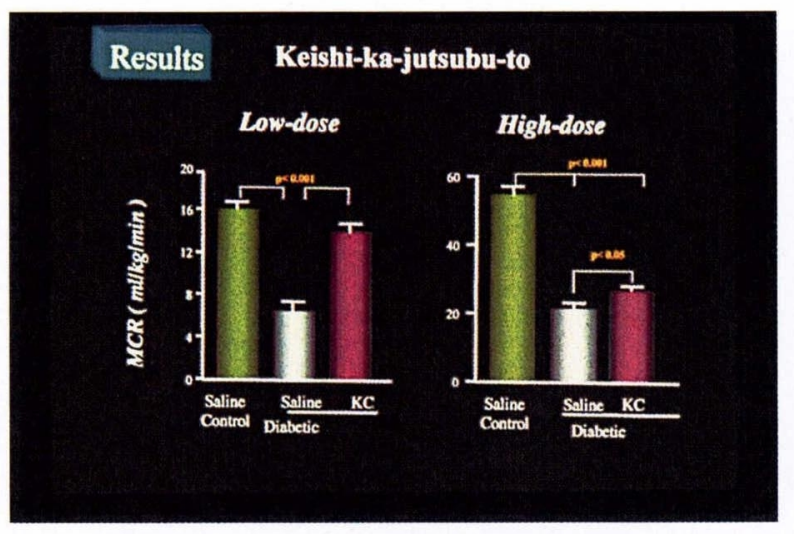

图32

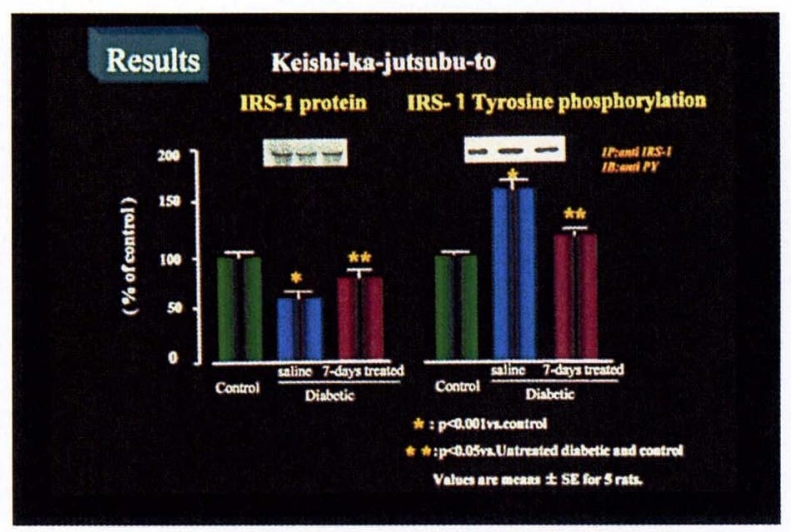

図34

療だけでなく，糖尿病そのものも予防する効果があ るのではないかと思っています。

午前中の石橋会長のご講演にもありましたが，い わゆる西洋薬ですとたくさんの種類の薬を使わなけ ればいけないのが，証をきっちり使ってうまくいけ ば単剤でいろいろな多くの症状を治すことができる ということですので，医療経済的に見ても非常に大 きい効果があるのではないかと思っています(図31)。

さらに，桂枝加术附湯でも幾つか，もうすでに3 本か 4 本論文を出していますので，簡単に紹介いた しますと（図32），桂枝加术附湯の場合も，STZ 糖 尿病で低下したGIR（インスリン感受性）が明らか に改善します。これも low-dose clamp で改善します。 STZ 糖尿病ラットだけでなく高果糖食, ですから, 果物をたくさん食べるということなのですけれども， 高果糖食インスリン抵抗性に対しても，桂枝加术附 湯および構成生薬の桂皮が有効であるということを 秦柏林先生は報告しています。

レセプターのたんぱく量に関して, STZ糖尿病 で増えます。先ほどの牛車腎気丸投与ではたんぱく 量は変わらなかったのですが，桂枝加术附湯では，

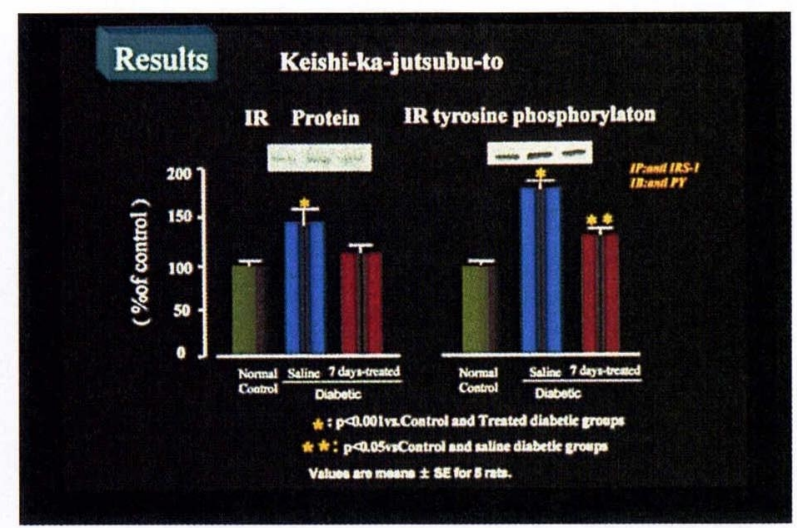

图33

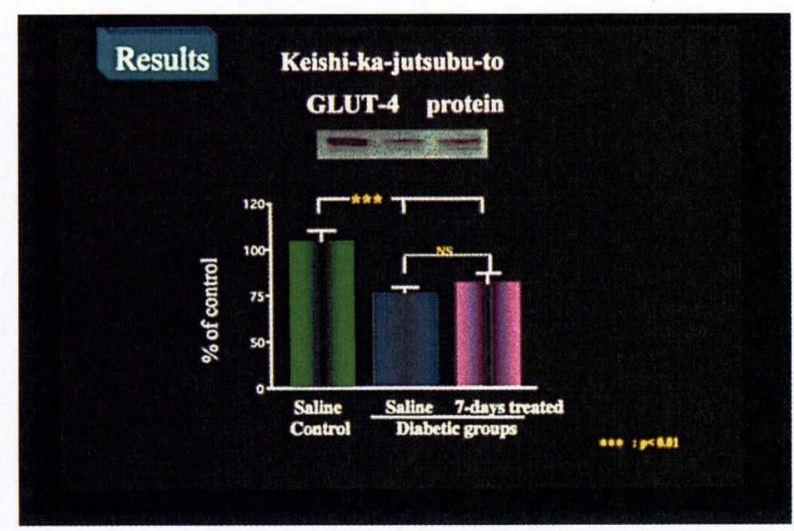

図35

たんぱく量も是正する力があります。それから，千 ロシンリン酸化も是正する作用があります（図33）。 それから, STZ 糖尿病では IRS-1 たんぱく量が低 下します。桂枝加术附湯投与はある程度は回復させ ます。それから IRS-1 のチロシンリン酸化もある程 度是正します（図34）。

GLUT 4 も調べているのですが, GLUT 4 に関し ては，どうも関係がないということが判明していま す（图35）。やはりインスリンシグナル伝達系路が 関係があるのではないかと思っています。

\section{5. 結語：糖尿病における漢方薬の適応}

時間も迫りましたのでまとめさせていただきます が，糖尿病における漢方薬の適応は次のように考え ています（表 6 ）。すなわち，糖尿病における漢方 薬の適応としては, 西洋医学的な診断を行い, 高血 圧も悪いのですが, 高血糖が悪いということははっ きりしていることですので，高血糖をとにかく見つ ける，見つけて治療します。

やはり西洋医学的に高血糖を重視して診断 ·治療 を行います。

漢方薬にはARIの作用や血管拡張作用などがあ 
表 6

\section{裾尿病における漢方薬の適応}

\section{1.西洋医学的診断・治療を併用}

2.合併症の早期治療と進展防止

\section{3.糖尿病(2型)の発症予防}

りますので, 合併症の早期発見・早期治療と進展防 止に用います。

さらには，牛車腎気丸や桂枝加术附湯はインスリ ン抵抗性を改善させる作用を持っており，2 型糖尿 病の発症予防にも役に立つのではないかと考えてい ます。先程石橋会長も漢方薬には予防効果があると いうことを扮っしゃっておられました。私は，牛車 腎気丸に関しましては, 日本で最初に糖尿病性神経 障害に有効であることを見つけましたが，当時は， 構成生薬のそれぞれの作用からその有効性のメカニ ズムを推定しただけですが，その後多くの先生方か ら客観的 evidence 発見していただき,メカニズ ムの多くの解明ができました。本当に私は大変貴重 な経験をさせていただきました。さらに糖尿病の発 症，インスリン抵抗性の改善作用があるという事実 も見い出すことができました。我々の分野では, 糖 尿病予防研究 (DPP : Diabetes Prevention Program) という有名な研究があり, 生活習慣を改善するのが, 経口血糖降下薬ビグアナイドよりも糖尿病の予防効 果が大きいという報告があります。

しかし，食事療法，運動療法の実施がより効果的 といっても, 達成率は $50 \%$ ぐらいです。トレーナー や栄養士さんなどがマンッーマンで指導してもやっ とその程度です。一方薬物療法達成率は $72 \%$ です。 したがいまして, 薬価の問題もありますが, 境界型 の人,さらには軽い患者さんに，例えば牛車腎気丸 や桂枝加尤附湯などを投与すると, 糖尿病の発症予 防も可能ではないかと思っている次第です。

ということで, 今日は石橋会頭に大変良い機会を お与えいただきまして，私が20年間に行って参りま した, 初めは臨床的な研究成績, それに基づいた幾 つかの動物実験成績, 若い大学院生などと行いまし
た研究成績をご紹介させていただきました。どうも ご静聴まことにありがとうございました。

渡辺 佐藤先生, どうもありがとうございました。 座長兼討論者ということになっているのですが, 本 当にぴったりお時間に終わっていただきました。今 の括話を聞いて非常に感銘を受けましたが，一つだ けお願いしたいことがございます。今，糖尿病の世 界ではビグアナイドと SU剤や，それにさらにピオ グリタゾンを加えるなど，コンビネーション・セラ ピーというものが行われています。血糖のコント ロールは, 恐らく10年前に比べるとかなりよくなっ ていると思うのですが, こうした中に，ぜひ漢方の コンビネーション・セラピーを, これは糖尿病学会 あたりでガイドラインを作っていただければ，非常 に勇気づけられるかなと思います。どうもありがと うございました。 